\title{
Characteristics of Microbiology of Deep Neck Abscess
}

\author{
Dong Hyun Kim, Hyo Geun Choi, Ji Hee Kim, Hyun Seok Kim, and Bumjung Park \\ Department of Otorhinolaryngology-Head and Neck Surgery, Hallym University Sacred Heart Hospital, \\ Hallym University College of Medicine, Anyang, Korea
}

\author{
심경부 감염의 세균학적 특징 \\ 김동현 · 최효근 · 김지희 · 김현석 · 박범정 \\ 한림대학교 의과대학 한림대학교 성심병원 이비인후-두경부외과학교실
}

Received December 2, 2013

Revised March 12, 2014

Accepted March 13, 2014

Address for correspondence

Bumjung Park, MD

Department of Otorhinolaryngology-

Head and Neck Surgery,

Hallym University

Sacred Heart Hospital,

Hallym University

College of Medicine,

22 Gwanpyeong-ro 170beon-gil,

Dongan-gu, Anyang 431-070, Korea

Tel $+82-31-380-3842$

Fax $+82-31-386-3860$

E-mail pbj426@hallym.or.kr
Background and Objectives This study aimed to review the characteristics of microbiology of deep neck abscess and to recommend adequate empirical antibiotics.

Subjects and Method Medical records of the 71 patients who underwent surgical drainage for deep neck abscess were reviewed retrospectively. We analyzed correlations between age, gender, etiology and diabetes mellitus and the cultured organism with respect to susceptibility of antibiotics.

Results The leading pathogens were Streptococcus viridians group (18.3\%), Klebsiella pneumonia (K. pneumonia, 15.5\%), Staphylococcus aureus (S. aureus, $15.5 \%$ ) and $\alpha$-hemolytic Streptococcus $(12.7 \%)$. The most common source of infection had a dental origin. Streptococcus viridians group was associated with infections of dental origin and $K$. pneumonia infection was overrepresented in the diabetic group compared to the non-diabetic group. Antibiotics susceptibility test showed that four leading pathogens were susceptible to ampicillin/sulbactam. The rate of methicillin-resistant $S$. aureus accounting for $S$. aureus infections was only $18.2 \%$.

Conclusion Only ampicillin/sulbactam without other antibiotics was sufficient to treat deep neck abscess empirically. Thus we suggest that other antibiotics that target anaerobes or 3rd generation cephalosporin are not necessary for the empirical treatments of deep neck abscess.

Korean J Otorhinolaryngol-Head Neck Surg 2014;57(6):379-83

Key Words Abscess · Antibiotics · Culture · Infection · Neck.

\section{서 론}

심경부 감염은 심경막과 심경부 공간에 연조직염 또는 농양 이 발생하는 감염성 질환이다. ${ }^{1)}$ 심경부 감염의 유병률과 합병 증은 진단기술과 항생제 치료의 발전으로 감소하고 있는 추세 지만 종격동염, 심낭염, 패혈증, 경정맥 혈전증, 급성 기도 폐색 같은 심각한 합병증을 일으킬 수 있으므로 즉각적인 진단 및 치료를 요한다. ${ }^{23)}$ 일반적으로 심경부 감염의 치료는 경험적 항 생제를 우선 투여하고 세균배양검사 결과가 나오면 그 결과에 맞추어 항생제를 변경하게 되며 필요시 절개 배농술을 시행 한다. ${ }^{3-5)}$ 심경부 농양의 외과적 절개 배농술 적응증으로는 항 생제 투여 48시간 후에도 증상이 악화될 때, 기도 폐쇄, 패혈증
이 동반된 경우, 종격동을 침범한 경우, 2군데 이상의 심경부 공간을 침범한 경우, 농양의 크기가 $3 \mathrm{~cm}$ 이상일 때 시행하는 것으로 알려져 있다. ${ }^{3)}$ 하지만 세균배양검사 결과가 보고되기 까지는 수일의 시간이 소요되므로, 세균배양검사에 의한 항 생제 사용보다는 초기에 경험적으로 어떤 항생제를 사용하는 지가 중요하다. 선행 연구에 따르면 그람 양성균, 그람 음성균, 혐기성균에 모두 항균력이 있는 경험적 항생제를 사용해야 하 며, penicillin 또는 3rd generation cephalosporin과 함께 metronidazole 또는 clindamycin을 병합하여 투여할 것을 추천 하고 있다. ${ }^{5,6)}$

본 연구에서는 심경부 감염 환자의 세균배양검사 결과를 분 석하여, 심경부 감염의 세균학적 특징을 파악하고 이에 따라 적 
절한 경험적 항생제를 추천하고자 하였다.

\section{대상 및 방법}

본 연구는 한림대학교성심병원 임상시험심사위원회의 승인 (2013-i098)을 받은 후 진행되었다.

2006년부터 2013년 6월까지 한림대학교성심병원 이비인후 과에서 심경부 감염으로 절개 배농술을 시행 받은 환자를 대 상으로 후향적 분석을 시행하였다. 내원 후 24시간 이내에 외 부 접근법(external approach)으로 절개 배농술을 시행하고 절개 배농술시 배농된 고름으로 호기성, 혐기성 세균배양검사 를 시행한 환자를 대상으로 하였으며 얕은 감염, 편도주위 농 양, 농양 형성이 되지 않은 심경부 연조직염의 경우에는 제외 하였다. 선정기준에 맞는 총 71 명의 환자를 대상으로 연구를 진행하였다. 패혈증이 동반된 경우, 전산화단층촬영에서 종격 동을 침범한 경우, 2 군데 이상의 심경부 공간을 침범한 경우, 농양의 크기가 $3 \mathrm{~cm}$ 이상인 경우의 모든 환자에서 24시간 이 내에 절개 배농술을 시행하였다. 모든 환자는 내원 즉시 경험 적 항생제로 ampicillin/sulbactam with metronidazole을 병 합하여 투여하였다.

나이, 성별, 감염원인, 당뇨 유병여부, 침범 부위, 백혈구 수 에 따라 보고되는 세균을 분석하였으며 보고된 세균의 항생 제 감수성 여부도 함께 분석하였다. 나이는 60 세를 기준으로 나누었으며, 감염원인은 문헌 고찰하여 감염을 일으키는 원 발 부위에 따라 치성감염, 침샘염, 임파선염, 상기도 감염, 원인 미상으로 나누었다. ${ }^{3,5,7)}$ 악하공간(submandibular space), 이악 하공간(submental space), 인구주위 공간(parapharyngeal space)에 농양이 발생한 모든 환자는 치과 협진하여 치성감염 을 감별하였다. 침범 부위는 이악하공간, 악하공간, 인구주위 공간(parapharyngeal space), 후인두공간(retropharyngeal space), 이하공간(parotid space)으로 나누었다. ${ }^{3.5)}$ 문헌 고찰에 의하면, 심경부 감염 환자에서 약물치료만 요하였던 군에 비 해 염증 정도가 심하여 수술적 치료를 시행해야 했던 환자들 에서 일반적으로 백혈구 수가 $15000 \mathrm{cell} / \mathrm{mm}$ 이상으로 높게 나 타난다고 알려져 있기 때문에 내원시 측정한 백혈구 수 15000 $\mathrm{cell} / \mathrm{mm}$ 를 기준으로 동정되는 세균을 분석하였다.

나이, 성별, 감염원인, 당뇨, 백혈구 수에 따라 동정되는 세균 은 Fisher의 정확한 검정을 통해 분석하였다. 세균별로 위험 인자 분석은 성별, 나이, 감염원인, 당뇨, 백혈구 수, 세균별 감 염의 위험 인자를 독립변수로, 감염균의 종류를 종속변수로 로지스틱 회귀 분석을 시행하였다. 통계 프로그램은 SPSS (ver. 12.0; SPSS Inc., Chicago, IL, USA)를 사용하였다.

\section{결 과}

세균배양검사는 Streptococcus viridians(S. viridians) group 이 13예(18.3\%)로 가장 높은 빈도를 보였고 Klebsiella pneumoniae(K. pneumoniae)와 Staphylococcus aureus(S. aures)가 각각 11예(15.5\%), $\alpha$-hemolytic Streptococcus 가 9 예(12.7\%) 순으로 동정되었다. 세균이 자라지 않은 경우는 20 예(28.2\%)였다(Table 1). 모든 환자는 치명적인 합병증 없이 회 복되었다.

71 명의 환자 중 남자는 42명(59.2\%), 여자는 29명(40.8\%)이 었으며 평균연령은 46.6 세 $( \pm 24.6)$ 이고 연령분포는 1 세부터 83 세까지였다. 세균배양검사 결과는 60 세 미만군과 이상군에서 S. aureus (20.9\% vs. 7.1\%, $p=0.181)$, S. viridians group $(14.0 \%$ vs. $25.0 \%, p=0.347), \alpha$-hemolytic Streptococcus $(11.6 \%$ vs. $14.3 \%, p=0.732)$, K. pneumoniae (9.3\% vs. $25.0 \%, p=0.098$ ) 모두 통계적으로 유의미한 차이는 없었다. 남녀군 간에도 $S . a u-$ $\operatorname{reus}(16.7 \%$ vs. $13.8 \%, p=1.000)$, S. viridians group $(19.0 \%$ vs. $17.2 \%, p=1.000)$, $\alpha$-hemolytic Streptococcus $(14.3 \%$ vs. $10.3 \%$, $p=0.729)$, K. pneumonia $(9.5 \%$ vs. $24.1 \%, p=0.110)$ 모두 유의 미한 차이는 없었다.

감염원인은 원인미상 27예(38.0\%)로 가장 흔하였고 치성감 염이 19예(26.8\%), 임파선염 13예(18.3\%), 상기도감염 6예(8.5\%), 침샘염 6예(8.5\%) 순으로 보고되었다. 치성감염의 경우 $S . v i-$ ridians $\operatorname{group}(42.1 \%, p=0.009)$ 이 흔하게 동정되었고 침샘염 의 경우 $K$. pneumoniae $(33.3 \%, p=0.008)$, 임파선염의 경우 $K$. pneumoniae $(46.2 \%, p=0.008)$ 가 흔하게 동정되었다. 상기도 감 염, 침샘염, 원인미상의 경우에 동정되는 세균은 통계적으로 유의미한 차이가 없었다.

침범 부위는 악하공간 39 명, 인두주위공간 31명, 후인두공간 21 명, 이악하공간 21 명, 이하공간 11 명이었으며 2개 이상의 공 간을 침범한 경우는 27명이었다. 후인두공간을 침범한 경우 $S$. viridians group $(33.3 \%, p=0.047)$ 이 흔하게 동정되었고 다른 부위를 침범한 경우나 2 개 이상의 공간을 침범한 경우에 동정 되는 세균은 통계적으로 유의미한 차이가 없었다.

기저질환으로 당뇨가 있었던 환자는 총 19명(26.8\%)이었고

Table 1. Culture results according to the organism in 71 patients

\begin{tabular}{lcc}
\hline \multicolumn{1}{c}{ Organism } & No. of patients & $\%$ \\
\hline No growth & 20 & 28.2 \\
Streptococcus viridians group & 13 & 18.3 \\
Klebsiella pnemoniae & 11 & 15.5 \\
Staphylococcus aureus & 11 & 15.5 \\
$\alpha$-hemolytic Streptococcus & 9 & 12.7 \\
Others & 7 & 9.9 \\
\hline
\end{tabular}


Characteristics of Microbiology of Deep Neck Abscess I Kim DH, et al.

Table 2. Characteristics of Klebsiella pneumoniae infection

\begin{tabular}{lccc}
\hline & Odds ratio & $95 \% \mathrm{Cl}$ & $\mathrm{p}$-value \\
\hline Diabetes mellitus & 7.317 & $1.447-36.989$ & 0.016 \\
Sialoadenitis & 9.02 & $1.006-80.909$ & 0.049 \\
Lymphadenitis & 12.366 & $2.127-71.877$ & 0.005 \\
Male & 2.688 & $0.260-27.762$ & 0.406 \\
WBC $\geq 15000 \mathrm{cell} / \mathrm{mm}$ & 0.398 & $0.053-3.001$ & 0.371 \\
\hline
\end{tabular}

WBC: white blood cell, Cl: confidence interval

Table 3. Antibiotics resistance of Streptococcus viridians group

\begin{tabular}{lcl}
\hline \multicolumn{1}{c}{ Antibiotics } & No. of resistance & $\%$ \\
\hline Ampicillin & 0 & 0 \\
Amoxicillin/clavulanate & 0 & 0 \\
Aminoglycoside & 0 & 0 \\
Quinolone & 0 & 0 \\
1st cephalosporin & 0 & 0 \\
2nd cephalosporin & 0 & 0 \\
3rd cephalosporin & 0 & 0 \\
4th cephalosporin & 0 & 0 \\
\hline
\end{tabular}

당뇨가 없는 환자에 비해 K. pneumoniae( $36.8 \%$ vs. $7.7 \%, p=$ 0.006)가 흔하게 동정되었다. K. pneumoniae는 당뇨가 있는 경우 7.317배( $p=0.016)$, 감염원인이 침샘염인 경우 9.020배( $p=$ $0.049)$, 임파선염인 경우 12.366 배 $(p=0.005)$ 감염될 확률이 높 았다(Table 2).

백혈구 수 $15000 \mathrm{cell} / \mathrm{mm}$ 미만군과 이상군의 동정되는 세 균을 비교하였을 때 $S$. aureus(15.4\% vs. 15.6\%, $p=1.000), S$. viridians group (17.9\% vs. $18.8 \%, p=1.000)$, $\alpha$-hemolytic Streptococcus $(10.3 \%$ vs. $15.6 \%, p=0.722)$, K. pneumoniae $(23.1 \%$ vs. $6.2 \%, p=0.096)$ 모두 통계적으로 유의미한 차이는 없었다.

세균별로 항생제 감수성 결과를 살펴보면 전체적으로 가장 흔하게 동정된 S. viridians group 은 ampicillin(0\%), amoxicillin/clavulate acid(0\%), quinolone(0\%), cephalosporin(0\%) 에 모두 내성이 없었다(Table 3). K. pneumoniae는 ampicillin 에 $100 \%$ 내성이 있었으나 amoxicillin/clavulate acid(0\%), quinolone(0\%), cephalosporin(0\%)에는 내성이 없었다(Table 4). S. aureus는 ampicillin에 81.8\% 내성이 있었으나 oxacillin, amoxicillin/clavulanate 내성률은 각각 $18.2 \%$ 로 낮게 보고되었다 (Table 5).

\section{고 찰}

본 연구에서는 S. viridians group(18.3\%)이 심경부 감염의 가장 흔한 원인이었으며, K. pneumoniae(15.5\%), S. aureus (15.5\%), $\alpha$-hemolytic Streptococcus $(12.7 \%)$ 순으로 보고되었 다. 세균이 자라지 않은 경우는 $28.2 \%$ 였으며 선행연구에서
Table 4. Antibiotics resistance of Klebsiella pneumoniae

\begin{tabular}{lcc}
\hline \multicolumn{1}{c}{ Antibiotics } & No. of resistance & $\%$ \\
\hline Ampicillin & 11 & 100 \\
Ampicillin/sulbactam & 0 & 0 \\
Aminoglycoside & 0 & 0 \\
Aztreonam & 0 & 0 \\
Quinolone & 0 & 0 \\
1st cephalosporin & 0 & 0 \\
2nd cephalosporin & 0 & 0 \\
3rd cephalosporin & 0 & 0 \\
4th cephalosporin & 0 & 0 \\
\hline
\end{tabular}

Table 5. Antibiotics resistance of Staphylococcus aureus

\begin{tabular}{lcc}
\hline \multicolumn{1}{c}{ Antibiotics } & No. of resistance & $\%$ \\
\hline Ampicillin & 9 & 81.8 \\
Amoxicillin/clavulanate & 2 & 18.2 \\
Aminoglycoside & 4 & 54.5 \\
1st cephalosporin & 0 & 0 \\
2nd cephalosporin & 0 & 0 \\
3rd cephalosporin & 0 & 0 \\
4th cephalosporin & 0 & 0 \\
Quinolone & 2 & 18.2 \\
Clindamycin & 4 & 34.4 \\
Oxacillin & 2 & 18.2 \\
Penicillin & 9 & 81.8 \\
Vancomycin & 0 & 0
\end{tabular}

도 11.8 51.5\% 정도로 보고되고 있다. ${ }^{3,8-10)}$ 내원하고 모든 환 자에 대해 24시간 이내에 수술적 치료를 시행하였지만, 내원 직전부터 수술 시행 전까지의 기간 동안에 항생제를 사용하 여 세균의 절대 수(bacterial load)가 감소하고 혐기성균 배양 검사의 어려움 때문인 것으로 판단된다. ${ }^{3,9)}$

감염의 원인에 따라 치성감염, 침샘염, 임파선염, 상기도 감 염, 원인미상으로 나누어 분석하였는데 이 중 치성감염이 심경 부 감염의 가장 주요 원인이었다(26.8\%). 다른 연구에서도 치 성감염이 심경부 감염의 가장 흔한 원인으로 $22.7 \sim 48.6 \%$ 를 차지하는 것으로 알려져 있다. ${ }^{3,5,8,9)}$

원인별로 동정되는 세균을 분석하였을 때, 치성감염에서는 구인두의 정상 세균총인 S. viridians group (42.1\%)이 가장 흔 하게 동정되었으며 이는 선행연구 결과와도 일치한다. ${ }^{11)}$ 이는 구강내 잇몸과 치아 주위에 존재하는 정상 세균총으로 알려 져 있기 때문이다. ${ }^{12)}$ 그 다음으로 치성감염에서 흔하게 동정 된 균은 S. aureus(10.5\%)이다. 따라서 치성감염이 의심되는 심경부 감염 환자의 경우 S. viridians group에 감수성이 있는 항생제를 사용하는 것이 추천된다. 본 연구에서 S. viridians group 은 ampicillin/clavulanate에 내성이 없는 것으로 나타 났다. 
심경부 감염 환자의 $26.8 \%$ 는 당뇨에 이환되어 있었으며, 당 뇨 환자들의 K. pneumoniae 감염은 $36.8 \%$ 로 당뇨가 없는 환 자들의 K. pneumoniae 감염 $(7.7 \%, p=0.003)$ 에 비해 높게 나타 났다. 이는 당뇨 환자들에서 중성구의 부착, 화학 주성, 살균 능력 등의 기능 저하와 보체 활성의 장애에 기인한다. ${ }^{13)}$ 당뇨 환 자에서는 중성구 면역력의 감소는 구인두의 K. pneumoniae 의 군집형성(colonization)을 증가시켜 심경부 감염의 원인이 된다고 알려져 있다. ${ }^{14)}$ 또한 불량한 혈당 조절이 중성구의 기능 저하와 관련이 있다는 보고가 있으므로 철저한 혈당 조절이 심경부 감염의 치료에 중요하다. ${ }^{15)}$ 본 연구에서 K. pneumoniae 에 대한 항생제 감수성 결과는 ampicillin에 내성이 있었으나 ampicillin/clavulanate에는 효과적으로 반응하는 것으로 나 타났다.

S. aureus는 두 번째로 흔하게 동정된 세균으로 피부와 점 막에 군집을 형성하여 기회감염을 일으키는 것으로 알려져 있 다. ${ }^{16)}$ S. aureus 감염 환자 중 methicillin-resistant S. aureus 비율은 $18.2 \%$ 로 낮게 나타났으며 methicillin에 대한 내성 기 전은 주로 변형된 penicillin binding protein(PBP)인 PBP $2 \mathrm{a}$ 가 $\beta$-lactam계 항생제와 친화력이 낮기 때문으로 알려져 있 다. ${ }^{17)}$ 본 연구에서 ampicillin에는 $81.8 \%$ 내성이 있었으나 ampicillin/clavulanate 내성률은 $18.2 \%$ 로 낮게 나타났다.

네 번째로 흔하게 동정된 $\alpha$-hemolytic Streptococcus는 Streptococcus intermedius, Streptococcus anginosus, Streptococcus constellatus 가 속하며 Streptococcus milleri group이 라고도 불린다. ${ }^{18)}$ 구강과 두경부 감염을 일으킬 수 있으며 농양 을 형성하는 경향을 보이고 본 연구에서 항생제 감수성 검사 를 시행하지는 않았지만 penicillin, cephalosporins, clindamycin, vancomycin에 모두 효과적으로 반응하는 것으로 알 려져 있다. ${ }^{19)}$ 따라서, ampicillin/sulbactam에도 효과적으로 반 응할 것으로 판단할 수 있다.

두경부 영역에 혐기성 감염을 일으키는 세균으로는 Bateroides, Prevotella, Porphyromonas asaccharolytica, Fusobacteria, Peptostreptococci, microaerophillic strepto$\operatorname{cocci}$ 등이 알려져 있으며 대부분의 혐기성 균에 효과가 있는 항생제로는 chloramphenicol, carbapenems, metronidazole, $\beta$-lactam/ $\beta$-lactamase inhibitor(ampicillin/sulbactam, piperacillin/tazobactam, ticarcillin/clavulanic acid)가 있다. ${ }^{20,21)}$ Clindamycin은 과거에는 혐기성 균 치료의 1차 선 택제였으나 최근 내성률이 점점 증가하여 더이상 혐기성 균의 1차 선택제로 사용되지 않는다. Bacteroides fragilis group에 대한 clindamycin 내성률은 1987년 3\%에서 2000년 26\%로 증가하였다. ${ }^{22,23)}$ Chloramphenicol과 metronidazole은 호기성 세균인 Gram positive cocci, Enterobacteriaceae에 대한 항균
력이 낮은 것으로 알려져 있다. ${ }^{20,21)}$

본 연구 결과를 종합하여 심경부 감염의 주요 원인균과 혐 기성 균에 모두 항균능력이 우수한 ampicillin/sulbactam이 심경부 감염의 경험적 항생제로 적절할 것으로 생각된다. 왜냐 하면, sulbactam은 clavulanic acid보다 넓은 스펙트럼을 가 진 $\beta$-lactamase inhibitor로 $\beta$-lactam계 항생제인 ampicilin 과 병합할 경우 amoxicillin/clavulanate의 항균범위와 함께 혐기성 균에도 매우 우수한 항균력을 가지는 것으로 알려져 있 고 $^{24,25)}$ 본 연구에서 심경부 감염의 주요 원인균인 S. viridians group, K. pnemoniae, S. aureus, $\alpha$-hemolytic Streptococcus는 ampicillin/sulbactam 또는 amoxicillin/clavulanate에 모두 효과적으로 반응하였기 때문이다.

\section{REFERENCES}

1) Wang LF, Kuo WR, Tsai SM, Huang KJ. Characterizations of lifethreatening deep cervical space infections: a review of one hundred ninety-six cases. Am J Otolaryngol 2003;24(2):111-7.

2) Bong JP, Kim SS, Heo W, Kim EJ, Park SI, Kim EG. Two cases of deep neck infection with mediastinal involvement. Korean J Otolaryngol-Head Neck Surg 1999;42(12):1587-92.

3) Boscolo-Rizzo P, Stellin M, Muzzi E, Mantovani M, Fuson R, Lupato V, et al. Deep neck infections: a study of 365 cases highlighting recommendations for management and treatment. Eur Arch Otorhinolaryngol 2012;269(4):1241-9.

4) Plaza Mayor G, Martínez-San Millán J, Martínez-Vidal A. Is conservative treatment of deep neck space infections appropriate? Head Neck 2001;23(2):126-33.

5) Bakir S, Tanriverdi MH, Gün R, Yorgancilar AE, Yildirim M, Tekbaş G, et al. Deep neck space infections: a retrospective review of 173 cases. Am J Otolaryngol 2012;33(1):56-63.

6) Marioni G, Staffieri A, Parisi S, Marchese-Ragona R, Zuccon A, Staffieri C, et al. Rational diagnostic and therapeutic management of deep neck infections: analysis of 233 consecutive cases. Ann Otol Rhinol Laryngol 2010;119(3):181-7.

7) Woo JH, Cha HE, Lee JH, Gang IG, Baek MK, Kim DY. Clinical analysis of factors affecting on treatment of deep neck infection. Korean J Otorhinolaryngol-Head Neck Surg 2008;51(6):544-8.

8) Eftekharian A, Roozbahany NA, Vaezeafshar R, Narimani N. Deep neck infections: a retrospective review of 112 cases. Eur Arch Otorhinolaryngol 2009;266(2):273-7.

9) Huang TT, Liu TC, Chen PR, Tseng FY, Yeh TH, Chen YS. Deep neck infection: analysis of 185 cases. Head Neck 2004;26(10):854-60.

10) Lee YQ, Kanagalingam J. Bacteriology of deep neck abscesses: a retrospective review of 96 consecutive cases. Singapore Med J 2011; 52(5):351-5.

11) Huang TT, Tseng FY, Yeh TH, Hsu CJ, Chen YS. Factors affecting the bacteriology of deep neck infection: a retrospective study of 128 patients. Acta Otolaryngol 2006;126(4):396-401.

12) Bryskier A. Viridans group streptococci: a reservoir of resistant bacteria in oral cavities. Clin Microbiol Infect 2002;8(2):65-9.

13) Katz S, Klein B, Elian I, Fishman P, Djaldetti M. Phagocytotic activity of monocytes from diabetic patients. Diabetes Care 1983;6(5):47982.

14) Har-El G, Aroesty JH, Shaha A, Lucente FE. Changing trends in deep neck abscess. A retrospective study of 110 patients. Oral Surg Oral Med Oral Pathol 1994;77(5):446-50.

15) Gallacher SJ, Thomson G, Fraser WD, Fisher BM, Gemmell CG, MacCuish AC. Neutrophil bactericidal function in diabetes mellitus: 
evidence for association with blood glucose control. Diabet Med 1995;12(10):916-20

16) Gordon RJ, Lowy FD. Pathogenesis of methicillin-resistant Staphylococcus aureus infection. Clin Infect Dis 2008;46 Suppl 5: S350-9.

17) Chambers HF, Hartman BJ, Tomasz A. Increased amounts of a novel penicillin-binding protein in a strain of methicillin-resistant Staphylococcus aureus exposed to nafcillin. J Clin Invest 1985;76 (1):325-31.

18) Whiley RA, Fraser H, Hardie JM, Beighton D. Phenotypic differentiation of Streptococcus intermedius, Streptococcus constellatus, and Streptococcus anginosus strains within the "Streptococcus milleri group". J Clin Microbiol 1990;28(7):1497-501.

19) Tracy M, Wanahita A, Shuhatovich Y, Goldsmith EA, Clarridge JE 3rd, Musher DM. Antibiotic susceptibilities of genetically characterized Streptococcus milleri group strains. Antimicrob Agents Chemother 2001;45(5):1511-4.

20) Brook I. Antimicrobial treatment of anaerobic infections. Expert Opin Pharmacother 2011;12(11):1691-707.
21) Hecht DW. Prevalence of antibiotic resistance in anaerobic bacteria: worrisome developments. Clin Infect Dis 2004;39(1):92-7.

22) Cornick NA, Cuchural GJ Jr, Snydman DR, Jacobus NV, Iannini P, Hill G, et al. The antimicrobial susceptibility patterns of the Bacteroides fragilis group in the United States, 1987. J Antimicrob Chemother 1990;25(6):1011-9.

23) Snydman DR, Jacobus NV, McDermott LA, Ruthazer R, Goldstein EJ, Finegold SM, et al. National survey on the susceptibility of Bacteroides Fragilis Group: report and analysis of trends for 19972000. Clin Infect Dis 2002;35(Suppl 1):S126-34.

24) Nguyen MH, Yu VL, Morris AJ, McDermott L, Wagener MW, Harrell L, et al. Antimicrobial resistance and clinical outcome of Bacteroides bacteremia: findings of a multicenter prospective observational trial. Clin Infect Dis 2000;30(6):870-6.

25) Snydman DR, Jacobus NV, McDermott LA, Ruthazer R, Golan Y, Goldstein EJ, et al. National survey on the susceptibility of Bacteroides fragilis group: report and analysis of trends in the United States from 1997 to 2004. Antimicrob Agents Chemother 2007;51(5):1649-55. 